\title{
Phylloplane bacteria increase seedling emergence, growth and yield of field-grown groundnut (Arachis hypogaea L.)
}

\author{
G.K. Kishore ${ }^{1}$, S. Pande ${ }^{2}$ and A.R. Podile ${ }^{1}$ \\ ${ }^{1}$ Department of Plant Sciences, University of Hyderabad, Hyderabad, India and ${ }^{2}$ Department of Pathology, International Crops \\ Research Institute for the Semi-Arid Tropics (ICRISAT), Patancheru, India
}

2004/0756: received 1 July 2004, revised 3 November 2004 and accepted 10 November 2004

\section{ABSTRACT}

G.K. KISHORE, S. PANDE AND A.R. PODILE. 2005.

Aim: To isolate and characterize groundnut-associated bacterial isolates for growth promotion of groundnut in field.

Methods and Results: Three hundred and ninety-three groundnut-associated bacteria, representing the geocarposphere, phylloplane and rhizosphere, and endophytes were applied as seed treatment in greenhouse.

Maximum increase in plant biomass (up to 26\%) was observed following treatment with a rhizosphere isolate identified as Bacillus firmis GRS 123, and two phylloplane isolates Bacillus megaterium GPS 55 and Pseudomonas aeruginosa GPS 21. There was no correlation between the production of L-tryptophan-derived auxins and growth promotion by the test isolates. Actively growing cells and peat formulations of GRS 123 and GPS 55, and actively growing cells of GPS 21, significantly increased the plant growth and pod yield (up to 19\%) in field.

Rifampicin-resistant mutants of GRS 123 and GPS 21 colonized the ecto- and endorhizospheres of groundnut, respectively, up to 100 days after sowing (DAS), whereas GPS 55 was recovered from both the habitats at 100 DAS. Conclusion: Seed bacterization with phylloplane isolates promoted groundnut growth indicating the possibility of isolating rhizosphere beneficial bacteria from different habitats.

Significance and Impact of the Study: Identification of phylloplane bacteria as effective plant growthpromoting rhizobacteria (PGPR) broadens the spectrum of PGPR available for field application.

Keywords: bacterial formulation, peanut, rhizosphere colonization, seed bacterization.

\section{INTRODUCTION}

Some rhizosphere bacteria, termed plant growth-promoting rhizobacteria (PGPR) (Kloepper and Schroth 1978), colonize the roots and promote growth and yield of crop plants in addition to disease control. Direct beneficial effects of PGPR are as a result of the production of plant growth hormones (mainly auxins), enhanced availability of nutrients to the host plant by production of siderophores and phosphate solubilization (Kloepper 1993), and production of volatiles

Correspondence to: A.R. Podile, Department of Plant Sciences, University of Hyderabad, Hyderabad 500 046, India (e-mail: arpsl@uohyd.ernet.in or podilerao@yahoo.com).

Present address: G. Krishna Kishore, Pathology, ICRISAT, Patancheru 502 324, India. such as 2,3-butanediol and acetoin (Ryu et al. 2003). Most often, it is difficult to distinguish growth promoting and biocontrol PGPR, as bacterial isolates selected for in vitro antibiosis frequently demonstrate growth promotion even in absence of the target pathogen. Similarly, PGPR selected for growth promotion had an ability to suppress the pathogens when challenge inoculated (reviewed by Kloepper 1993).

Seed treatment with rhizobacteria or their formulations increased the growth of maize (Jacoud et al. 1999), wheat (Khalid et al. 2004), rice (Preeti et al. 2002), and several other crops (Podile and Dube 1988; Kloepper et al. 1991). The observed growth promotion is based on several parameters including increase in plant nutrient uptake, root length, shoot length, branching, nodulation (in legume crops), dry biomass, yield and seed weight. The use of these

(C) 2005 The Society for Applied Microbiology 
beneficial bacteria as biofertilizers has increased interest worldwide, to attain sustainability in agriculture.

Until now, a large majority of the beneficial bacteria identified for use as PGPR were isolated from the rhizosphere and a few of these have been classed as endophytes (Manjula et al. 2002; Sessitsch et al. 2004). There is a possibility for selection of PGPR from other plant habitats to broaden the spectrum of PGPR and identify more potent PGPR. Bacteria that colonize the aerial plant parts such as the phylloplane are exposed to higher temperature and moisture fluctuations with limited nutrient availability and such bacteria have a better chance to survive and multiply in a nutritionally rich, buffered rhizosphere soil. The phylloplane provides a diversity of beneficial bacteria because of the frequent drift in the microbial communities. Phylloplane bacteria have been identified as biocontrol agents in the phylloplane (Andrews 1992) but have not been tested in other habitats such as the rhizosphere.

Groundnut or peanut (Arachis hypogaea L.) is an important oilseed crop in rain-fed areas of Asia and Africa, and soil fertility is an important constraint for high pod yields. The majority of the small-scale farmers in these regions are reluctant to invest in chemical fertilizers because of the unassured crop returns owing to the high incidence of fungal diseases and unpredictable terminal drought. In this context, there is a greater scope for development and popularization of bioinoculants in these groundnut production systems. Earlier attempts for selection of PGPR for groundnut growth promotion in Indian soils identified an increase in pod yield following seed treatment with Pseudomonas sp. (Pal et al. 2000). In the present study, we have evaluated the effects of groundnut-associated bacteria on the growth of groundnut both in greenhouse and field. Bacteria including endophytic and phylloplane isolates were compared with rhizospheric isolates for their possible use as PGPR.

\section{MATERIALS AND METHODS}

\section{Isolation of bacteria}

Groundnut plants collected from 17 different fields of the International Crops Research Institute for the Semi-Arid Tropics (ICRISAT, Patancheru, India), and 55 farmers' fields in nine districts of Andhra Pradesh (India) (Table 1) were used for isolation of groundnut-associated bacteria. The groundnut cultivars in the sampled fields were the traditional cultivars adopted by the farmers and locally multiplied, and resembled TMV 2/JL 24. In each field three apparently healthy plants of 70-100 days old were collected from two different sites, which were considered as two replications. The collected plants were used for isolation of bacterial strains associated with different habitats of groundnut, that is, geocarposphere (soil region around the pod), phylloplane and rhizosphere, and endophytes of leaf, root and seed. Ten grams
Table 1 Village/locations distributed in nine districts of Andhra Pradesh, India, from which field-grown groundnut plants were collected for isolation of groundnut-associated bacterial strains

\begin{tabular}{ll}
\hline District & Village/location \\
\hline Anantapur & Danduvaripalli, Kadiri, Kottapalli* \\
Chittoor & Ballaiahgaripalli, Doulatkhanpalli, Gollapalli \\
Cuddapah & Akkampeta, Dennemeedipalli, Dennepadu, \\
& Erakatollapalli, Kolomollapally, \\
& Maddimadugu, Nagavurpalli, Pakherpalli, \\
& Veeraponianipalli, Venkatareddigaripalli \\
Kandlakunta*, Yallamanda \\
Kuntur & Bastipadu, Brahmanakotkuru, Errakota*, \\
& Gonegundla, Goramanakonda tanda, \\
& K. Nagalapuram, Meedi vemula, Mugithi, \\
& Nannuru, Narnur, Pedakottala, \\
& Penchikilapadu, Puttapasham, Pyalakurthi \\
and Vishwanathapuram \\
MahaboobNagar & Elikicherla*, Kottalagadda*, Vuyyalavada* \\
Medak & Inavolu*, Kolluru* and Sankarapalli \\
Nalgonda & Dupadu*, Gaddipally* and Macharam* \\
RangaReddy & Rajendra Nagar, Gacchibowli \\
\hline
\end{tabular}

In each village, groundnut plants were collected from one field. *The collection of samples from two fields in the same village. All the fields in Guntur and Medak districts had black soil, Nalgonda and Mahaboobnagar are red soil fields and others are red sandy soils. The collected plants were of locally adopted groundnut cultivars and sampling was carried out at 70-100 days after sowing.

of rhizosphere/geocarposphere soil and leaves were suspended in $90 \mathrm{ml}$ of $20 \mathrm{~mm}$ phosphate buffer, $\mathrm{pH} 7 \cdot 0$ and incubated for $1 \mathrm{~h}$ at $200 \mathrm{rev} \mathrm{min}^{-1}$ and $30^{\circ} \mathrm{C}$. For isolation of endophytic bacteria, $5 \mathrm{~g}$ of leaf/root/seed, surface sterilized for $5 \mathrm{~min}$ with $70 \%$ ethanol, was homogenized in $20 \mathrm{ml}$ of the sterilized phosphate buffer using a mortar and pestle. Appropriate dilutions of these suspensions were plated on one-fourth strength of Luria-Bertani (LB) agar (composition of full strength LB agar: tryptone $10 \mathrm{~g}$, yeast extract $5 \mathrm{~g}, \mathrm{NaCl}$ $10 \mathrm{~g}$ and agar $15 \mathrm{~g}$ per $1000 \mathrm{ml}$ distilled water and $\mathrm{pH}$ adjusted to $7 \cdot 0$ ) and incubated for $72 \mathrm{~h}$ at $30^{\circ} \mathrm{C}$. In each sample, single colonies of predominant strains with distinct morphologies and well separated from the others, were subcultured and preserved as glycerol stocks at $-70^{\circ} \mathrm{C}$. Bacterial isolates were designated based on their habitat of isolation: GRS - rhizosphere, GPS - phylloplane, GGS geocarposphere, GSE - seed endophytes, GRE - root endophytes and GLE - leaf endophytes ( $G$ stands for groundnut).

\section{Greenhouse evaluation of plant growth promoting activity of groundnut-associated bacteria}

Three hundred and ninety-three groundnut-associated bacterial isolates were evaluated for their plant growth- 
promoting activity on groundnut in the greenhouse. Seeds of groundnut cv. TMV 2 were surface sterilized with $0.02 \%$ (w/v) $\mathrm{HgCl}_{2}$ and washed three times with sterile distilled water (SDW) to remove traces of $\mathrm{HgCl}_{2}$. Bacterial isolates were grown as a lawn on LB agar in $90 \mathrm{~mm}$ diameter Petri plates for $48 \mathrm{~h}$ at $30^{\circ} \mathrm{C}$. The cells were scraped into $20 \mathrm{ml}$ of $0.5 \%$ carboxy methyl cellulose (CMC) and the surfacesterilized seeds were suspended in this cell suspension for $30 \mathrm{~min}$. Bacterized seeds were dried under a flow of sterile air in a laminar flow for $4-5 \mathrm{~h}$ before sowing. The viable cell count as determined by dilution plating was $10^{6}-10^{7} \mathrm{CFU}$ seed $^{-1}$.

Five bacterized seeds with 0.5\% CMC-treated seeds as control were planted in $15 \mathrm{~cm}$ diameter plastic pots filled with red alfisol and sand $(3: 1)$. The $\mathrm{pH}$ of the alfisol was 6.8 and its mineral content was as follows: organic C, $0.68 \%$, P, $6.1 \mathrm{ppm}, \mathrm{N}, 813 \mathrm{ppm}, \mathrm{B}, 0.26 \mathrm{ppm}, \mathrm{Zn}, 1.42 \mathrm{ppm}, \mathrm{Cu}$, $23.4 \mathrm{ppm}, \mathrm{Mn}, 2.82 \mathrm{ppm}, \mathrm{Fe}, 21.08 \mathrm{ppm}, \mathrm{K}, 186 \mathrm{ppm}$ and $\mathrm{Mg}, 336 \mathrm{ppm}$. The temperature in the greenhouse was maintained at $28 \pm 2{ }^{\circ} \mathrm{C}$ and the pots were adequately watered daily. The emergence of seedlings was recorded 7 days after sowing (DAS). The plants were uprooted 20 DAS to measure the root and shoot lengths. The plants were washed, dried in an oven at $80^{\circ} \mathrm{C}$ for $24 \mathrm{~h}$ and the dry weight was recorded. In each treatment, 10 seeds were planted per replication. The experiment was conducted in a completely randomized block design with three replications in each treatment and repeated twice.

\section{Auxin production and mineral phosphate solubilization by groundnut-associated bacteria}

The 393 groundnut-associated bacterial isolates were tested for production of auxins in L-tryptophan-amended medium by immobilization on to a nitrocellulose membrane (Bric et al. 1991). Mineral phosphate solubilization (MPS) was noted as a clearance zone of $\mathrm{Ca}_{3}\left(\mathrm{PO}_{4}\right)_{2}$ in Pikovsky's agar medium (Pikovsky 1948). The diameter of the clearance zone was measured in $\mathrm{mm} 7$ days after incubation. The experiments were conducted twice with three replications.

\section{Identification of selected bacterial isolates}

Bacterial isolates with potential plant growth promoting activity were identified at Microbial Type Culture Collection and Gene Bank of Institute of Microbial Technology (Chandigarh, India) based on morphological, growth and biochemical characteristics.

\section{Evaluation of peat-based formulations of selected isolates in field}

Peat-based formulations of three bacterial isolates, that is, Bacillus firmis GRS 123, Bacillus megaterium GPS 55 and
Pseudomonas aeruginosa GPS 21, selected for plant growth promotion in greenhouse, were further tested in field. Neutralized peat (Biocare Technology Pvt. Ltd, Chatswood, NSW, Australia) was packed in high molecular and high density polyethylene bags, and sterilized at $121^{\circ} \mathrm{C}$ for $20 \mathrm{~min}$. Bacterial cultures grown in LB broth for $16 \mathrm{~h}$ at $30^{\circ} \mathrm{C}$ and $180 \mathrm{rev} \min ^{-1}$ were centrifuged for $5 \mathrm{~min}$ at $3600 \mathrm{~g}$ and $4^{\circ} \mathrm{C}$, and the harvested cells were resuspended in $10 \mathrm{~mm}$ phosphate buffer, $\mathrm{pH} 7 \cdot 0$ at a 100 -fold dilution. One hundred grams of neutralized peat was asceptically inoculated with $50 \mathrm{ml}$ of the diluted cell suspension with uniform adsorption of the bacterial cells into peat and incubated at $30^{\circ} \mathrm{C}$. Moisture loss of the formulation determined from the loss in initial weight was frequently compensated by the addition of SDW. Viable cell count of the formulations was determined by dilution plating on nutrient/LB agar and expressed as $\log \mathrm{CFU} \mathrm{g}{ }^{-1}$. The experiment was repeated twice with four replications.

The experiment was conducted in red alfisols of ICRISAT, Patancheru during khariff (rainy season) of 2001 and repeated in 2002. The experimental field, with a soil $\mathrm{pH}$ of $6 \cdot 7$, has been used for cultivation of groundnut/sorghum/ pearl millet for nearly 30 years. Single super phosphate and gypsum $\left(375 \mathrm{~kg} \mathrm{ha}^{-1}\right)$ during ploughing and peg initiation, respectively, were applied. Chlorothalonil $\left(2 \mathrm{~g} \mathrm{l}^{-1}\right.$, Kavach $^{\circledR}$, Syngenta India Ltd, Mumbai, India) was applied twice at $\mathbf{5 5}$ and 80 DAS to control foliar diseases. In both years, planting was carried out in the fourth week of June and the plants were harvested in the second week of October. Weekly averages of the weather parameters (rainfall $(\mathrm{mm})$, maximum and minimum temperatures $\left({ }^{\circ} \mathrm{C}\right)$ ) during the crop season in both the years is provided in Fig. 1.

Each treatment consisted of four rows of $9 \mathrm{~m}$ length with an intra- and inter-row spacing of 15 and $60 \mathrm{~cm}$, respectively, and replicated three times in a completely randomized block design. Seed bacterization with actively growing bacteria was similar to that described for greenhouse evaluations. For seed bacterization with bacterial formulations, $100 \mathrm{~g}$ of surface sterilized seeds were mixed thoroughly with $2 \mathrm{~g}$ of the 90-day-old peat formulation using $0.5 \% \mathrm{CMC}$ as an adhesive. Seeds treated with CMC alone served as control. The experimental plots were irrigated 1 day before planting and the seeds were planted at a $10-\mathrm{cm}$ depth in a furrow made at the time of planting and immediately covered to retain the moisture. All the treatments were also planted in two additional rows of $4 \mathrm{~m}$ length to uproot the plants for periodical observations. Starting from 20 DAS, four randomly selected plants were uprooted from each treatment for measurement of root length, shoot length and dry biomass. At physiological maturity (110 DAS), the experimental plots were irrigated and the plants were uprooted manually. The pods were hand picked, sun-dried and the recorded yield in individual treatment was calculated as $\mathrm{tha}^{-1}$. 

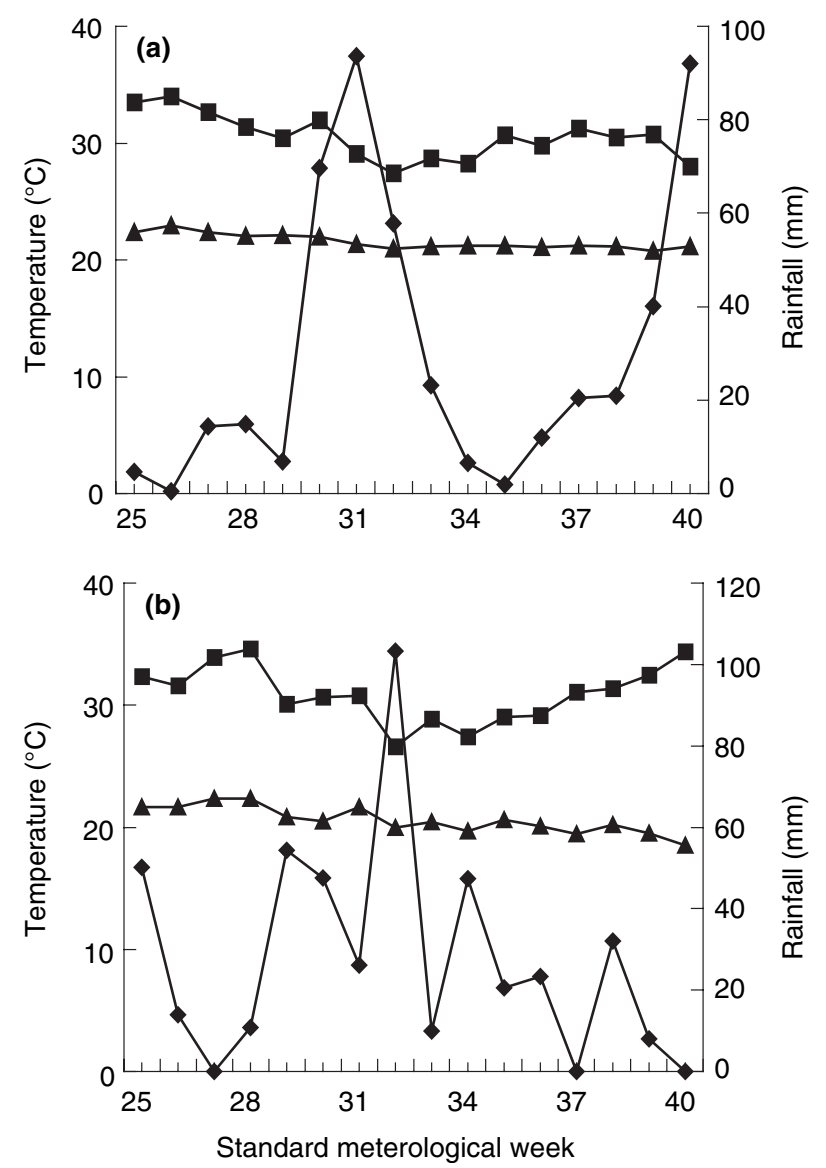

Fig. 1 Weather parameters $(\diamond)$ rainfall in $\mathrm{mm},(\boldsymbol{\square})$ maximum temperature and $(\boldsymbol{\Delta})$ minimum temperature near the experimental field at ICRISAT, Patancheru, India. The average of the weather parameters for each standard meteorological week during the experiment in the years (a) 2001 and (b) 2002 is presented

\section{Rhizosphere colonization of growth promoting bacteria in field}

Rhizosphere colonization of the rhizosphere isolate $B$. firmis GRS 123 and phylloplane isolates B. megaterium GPS 55 and $P$. aeruginosa GPS 21 in field was determined by using rifampicin resistance as a marker. Growth of GRS 123 and GPS 55, and GPS 21 was observed sensitive to the presence of 1 and $5 \mu \mathrm{g} \mathrm{ml}^{-1}$ rifampicin, respectively, in nutrient/LB agar. Spontaneous mutants of these bacteria with tolerance to higher concentrations of rifampicin were obtained by plating on nutrient/LB agar with 50 and $100 \mu \mathrm{g} \mathrm{ml}^{-1}$ rifampicin. The mutants, observed after $96 \mathrm{~h}$ of incubation, were evaluated for stable antibiotic resistance by repeated subculturing (at least 20 times) on rifampicin $\left(100 \mu \mathrm{g} \mathrm{ml}^{-1}\right)$ added agar medium. Stable mutants of GRS 123, GPS 55 and GPS 21 designated as GRS $123-\mathrm{R}_{1}$, GPS 55- $\mathrm{R}_{1}$ and GPS 21- $\mathrm{R}_{1}$, similar to the wild isolates in their morphology, in vitro growth and plant growth promotion in greenhouse, were applied to the seed and their survival in the ecto- and endorhizosphere of groundnut in field was quantified. Seed bacterization with the rifampicin-resistant mutants was performed as described for greenhouse evaluation and the bacterized seeds were used for field planting. The location, design and method of field experiment was similar to that previously described except that only a single row of $4 \mathrm{~m}$ length was planted in each treatment.

For each treatment two plants per replication were uprooted at a 20-day-interval and a 2-3-cm segment from the middle portion of the root along with the tightly adhering soil was suspended in $50 \mathrm{ml}$ of $2 \mathrm{mM}$ phosphate buffer, $\mathrm{pH} 7 \cdot 0$. The suspension was incubated for $1 \mathrm{~h}$ at $180 \mathrm{rev} \mathrm{min}^{-1}$ and $30^{\circ} \mathrm{C}$. To quantify the colonization of endorhizosphere by the introduced bacteria, the root segments were surface sterilized with $70 \%$ ethanol and homogenized in sterile $20 \mathrm{mM}$ phosphate buffer, $\mathrm{pH} 7 \cdot 0$. Serial dilutions of both the suspensions were plated on nutrient/LB agar with $100 \mu \mathrm{g} \mathrm{ml}^{-1}$ rifampicin, with three plates per dilution and incubated for $48 \mathrm{~h}$ at $30^{\circ} \mathrm{C}$. Bacterial population in individual treatment was expressed as $\log \mathrm{CFU} \mathrm{g}{ }^{-1}$. The experiment was conducted in the 2001 and 2002 rainy seasons, with three replications in each treatment.

\section{Data analysis}

All the greenhouse and field experiments for plant growth promotion were arranged in a completely randomized block design. The data were subjected to analysis of variance (ANOVA) using the Genstat 5 statistical package (Lawes Agricultural Trust, Rothamsted, UK). The survival of growth promoting isolates in formulations and in rhizosphere was log transformed before subjecting to ANOVA. The mean values in each treatment were compared using least significant differences at $5 \%(P=0.05)$ level of significance.

\section{RESULTS}

\section{Isolation of bacteria}

Three hundred and ninety-three groundnut-associated bacteria were isolated from different habitats of field-grown groundnut plants representing all major groundnut growing areas of Andhra Pradesh (India). Isolates from individual fields differed in their colony morphology. The number of bacterial strains isolated from individual habitats is as follows: rhizosphere $250(63.6 \%)$, phylloplane 67 (17\%), geocarposphere $13(3.3 \%)$, leaf endophyte $1(0 \cdot 3 \%)$, root endophytes $5(1 \cdot 3 \%)$ and seed endophytes 57 (14.5\%). 


\section{Greenhouse evaluation of plant growth promoting activity of groundnut-associated bacteria}

Of the 393 bacterial isolates tested, 27, representing the geocarposphere, rhizosphere, phylloplane and seed of groundnut, significantly $(P=0.05)$ improved the dry biomass and root length in repeated greenhouse experiments (Table 2). All of the 27 isolates except GRS 49, GRS 60 and GRS 86, increased shoot length of treated seedlings. Maximum root length $(60 \%$ over control $)$ was observed following seed treatment with GRS 180, while the highest increase in dry biomass occurred with a phylloplane isolate B. megaterium GPS $55(26 \%)$ followed by another phylloplane isolate $P$. aeruginosa GPS $21(24 \%)$ and a rhizobacterium B. firmis GRS 123 (24\%). These three bacteria also effectively increased the root and shoot length by $>43$ and $>32 \%$ respectively. Four of the 393 bacterial isolates were deleterious to the groundnut growth as observed by a significant reduction of plant biomass (data not shown).

\begin{tabular}{|c|c|c|c|c|c|c|}
\hline Isolate* & $\begin{array}{l}\text { Habitat of } \\
\text { isolation }\end{array}$ & $\begin{array}{l}\text { Root length } \\
\text { (cm) }\end{array}$ & $\begin{array}{l}\text { Shoot length } \\
\text { (cm) }\end{array}$ & $\begin{array}{l}\text { Dry weight } \\
\text { (g) }\end{array}$ & Auxin $\dagger$ & MPS \\
\hline GGS 6 & geocarposphere & $18 \cdot 6(37)$ & $12 \cdot 1(22)$ & $2 \cdot 73(17)$ & - & $1 \cdot 0$ \\
\hline GPS 21 & phylloplane & $19 \cdot 5(43)$ & $13 \cdot 1(32)$ & $2 \cdot 91(24)$ & + & - \\
\hline GPS 28 & phylloplane & $17 \cdot 8(31)$ & $12 \cdot 2(23)$ & $2 \cdot 75(18)$ & - & - \\
\hline GPS 32 & phylloplane & $18 \cdot 6(37)$ & $12 \cdot 4(25)$ & $2 \cdot 74(17)$ & - & $0 \cdot 2$ \\
\hline GPS 38 & phylloplane & $16 \cdot 2(19)$ & $12 \cdot 3(24)$ & $2 \cdot 70(15)$ & + & - \\
\hline GPS 55 & phylloplane & $20 \cdot 1(48)$ & $14 \cdot 2(43)$ & $2 \cdot 95(26)$ & + & - \\
\hline GRS 2 & rhizosphere & $17 \cdot 6(29)$ & $11.9(20)$ & $2 \cdot 80(20)$ & + & - \\
\hline GRS 7 & rhizosphere & $15 \cdot 8(16)$ & $11 \cdot 0(11)$ & $2 \cdot 71(16)$ & + & - \\
\hline GRS 11 & rhizosphere & $16 \cdot 2(19)$ & $11 \cdot 7(18)$ & $2 \cdot 80(20)$ & - & - \\
\hline GRS 18 & rhizosphere & $17 \cdot 1(26)$ & $11 \cdot 0(11)$ & $2 \cdot 71(16)$ & - & - \\
\hline GRS 49 & rhizosphere & $17 \cdot 4(28)$ & $10 \cdot 9(10)$ & $2 \cdot 68(15)$ & + & - \\
\hline GRS 60 & rhizosphere & $16 \cdot 4(21)$ & $10 \cdot 5(6)$ & $2 \cdot 69(15)$ & - & - \\
\hline GRS 69 & rhizosphere & $18 \cdot 6(37)$ & $12 \cdot 2(23)$ & $2 \cdot 71(16)$ & - & - \\
\hline GRS 73 & rhizosphere & $16 \cdot 4(21)$ & $12 \cdot 3(24)$ & $2 \cdot 68(15)$ & - & - \\
\hline GRS 86 & rhizosphere & $15.9(17)$ & $10 \cdot 8(9)$ & $2 \cdot 74(17)$ & - & - \\
\hline GRS 96 & rhizosphere & $17 \cdot 7(30)$ & $12.9(30)$ & $2 \cdot 68(15)$ & + & - \\
\hline GRS 115 & rhizosphere & $18 \cdot 9(39)$ & $12.9(30)$ & $2 \cdot 77$ (18) & + & - \\
\hline GRS 123 & rhizosphere & $19 \cdot 5(43)$ & $13 \cdot 4(35)$ & $2 \cdot 89(24)$ & - & - \\
\hline GRS 128 & rhizosphere & $17 \cdot 5(29)$ & $12 \cdot 3(24)$ & $2 \cdot 77(18)$ & - & - \\
\hline GRS 143 & rhizosphere & $18 \cdot 8(38)$ & $12 \cdot 5(26)$ & $2 \cdot 74(17)$ & + & $0 \cdot 1$ \\
\hline GRS 180 & rhizosphere & $21 \cdot 8(60)$ & $12 \cdot 2(23)$ & $2 \cdot 74(17)$ & + & $0 \cdot 1$ \\
\hline GRS 183 & rhizosphere & $16 \cdot 8(24)$ & $12 \cdot 0(21)$ & $2 \cdot 79(19)$ & - & - \\
\hline GRS 192 & rhizosphere & $18 \cdot 2(34)$ & $12 \cdot 5(26)$ & $2 \cdot 75(18)$ & - & - \\
\hline GRS 203 & rhizosphere & $19 \cdot 1(40)$ & $11 \cdot 6(17)$ & $2 \cdot 78(19)$ & - & $0 \cdot 3$ \\
\hline GRS 241 & rhizosphere & $18 \cdot 7(38)$ & $11 \cdot 7(18)$ & $2 \cdot 70(15)$ & - & - \\
\hline GSE 18 & seed endophyte & $16 \cdot 3(20)$ & $11.5(16)$ & $2.69(15)$ & - & $0 \cdot 7$ \\
\hline GSE 28 & seed endophyte & $20 \cdot 0(47)$ & $12 \cdot 0(21)$ & $2 \cdot 70(15)$ & - & - \\
\hline Control & & $13 \cdot 6(0)$ & $9.9(0)$ & $2 \cdot 34(0)$ & & \\
\hline $\begin{array}{l}\text { LSD } \\
\qquad(P=0 \cdot 05)\end{array}$ & & $1 \cdot 41$ & $1 \cdot 05$ & $0 \cdot 33$ & & \\
\hline
\end{tabular}

Table 2 Effect of seed treatment with groundnut-associated bacteria on growth of groundnut in greenhouse

Values in parenthesis indicate the percentage increase over control.

*Twenty-seven bacterial isolates that significantly increased the biomass of groundnut, among the evaluated 393 groundnut-associated bacterial isolates, are listed. Bacterized seeds of groundnut cv. TMV 2 planted in a potting mixture (red alfisol and sand, $3: 1$ ) in greenhouse, and root length, shoot length and dry biomass were measured 20 DAS. Data is the mean of 90 plants in nine replications.

$\dagger$ Auxin production was determined by immobilization on to nitrocellulose membrane and colour development with Salkowski's reagent.

$\$$ Mineral phosphate solubilization (MPS) of the bacterial isolates was measured as diameter (in millimetres) of the clearance zone on Pikovsky's medium containing $\mathrm{Ca}_{3}\left(\mathrm{PO}_{4}\right)_{2}$ after 7 days of incubation. 


\section{Auxin production and MPS by groundnut- associated bacteria}

Of the 393 groundnut-associated bacterial isolates, $39(10 \%)$ produced auxin on L-tryptophan-amended medium and 50 $(13 \%)$ solubilized $\mathrm{Ca}_{3}\left(\mathrm{PO}_{4}\right)_{2}$. The percentage of auxin producers and phosphate solubilizers among the 27 plant growth-promoting isolates was high compared with their percentage among all the test isolates (Fig. 2). Few of the bacterial isolates that did not produce auxin in vitro were

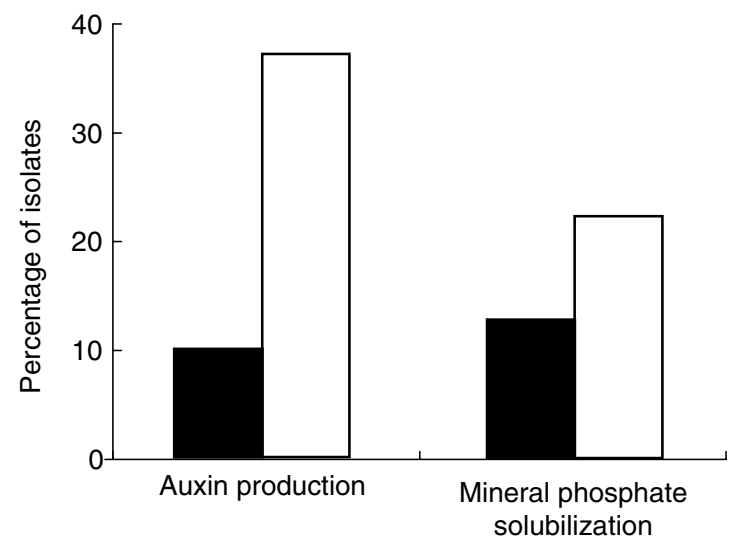

Fig. 2 In vitro auxin production and mineral phosphate solubilization by groundnut-associated bacteria. ( $\square$ ) Percentage of isolates positive for individual characteristic among the total 393 bacterial isolates was compared with $(\square)$ percentage of isolates positive among the 27 growth promoting isolates

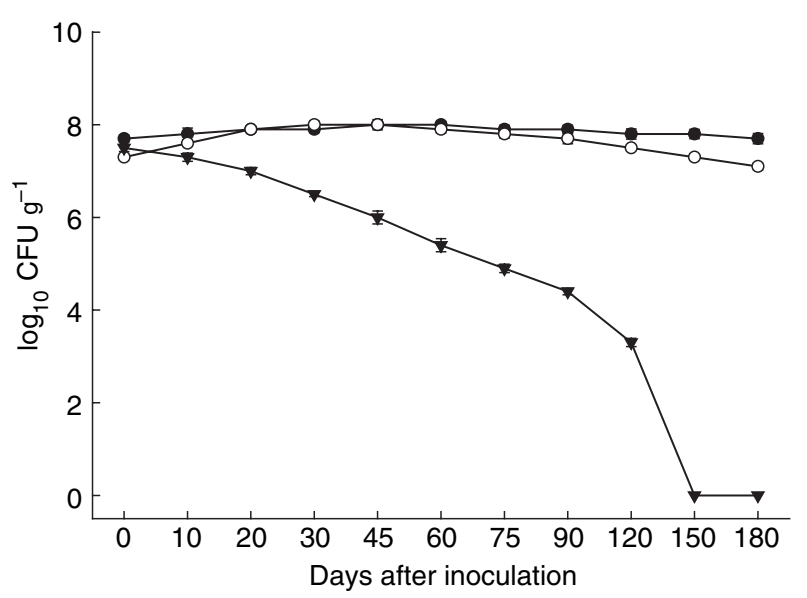

Fig. 3 Survival of selected groundnut-associated bacteria $(\bullet)$ Bacillus firmis GRS 123, (○) Bacillus megaterium GPS 55 and ( $)$ Pseudomonas aeruginosa GPS 21 in peat-based formulations. Neutralized sterile peat was inoculated with $50 \%(\mathrm{v} / \mathrm{w})$ of a suspension of mid-log phase cells and incubated at $30^{\circ} \mathrm{C}$. Viable cell count was determined at regular time intervals by dilution plating. Data points are the mean and standard error of 12 replications in each treatment as effective as auxin producers in promotion of root growth. Compared with phosphate-solubilizing bacteria, the majority of the auxin producers enhanced the plant growth.
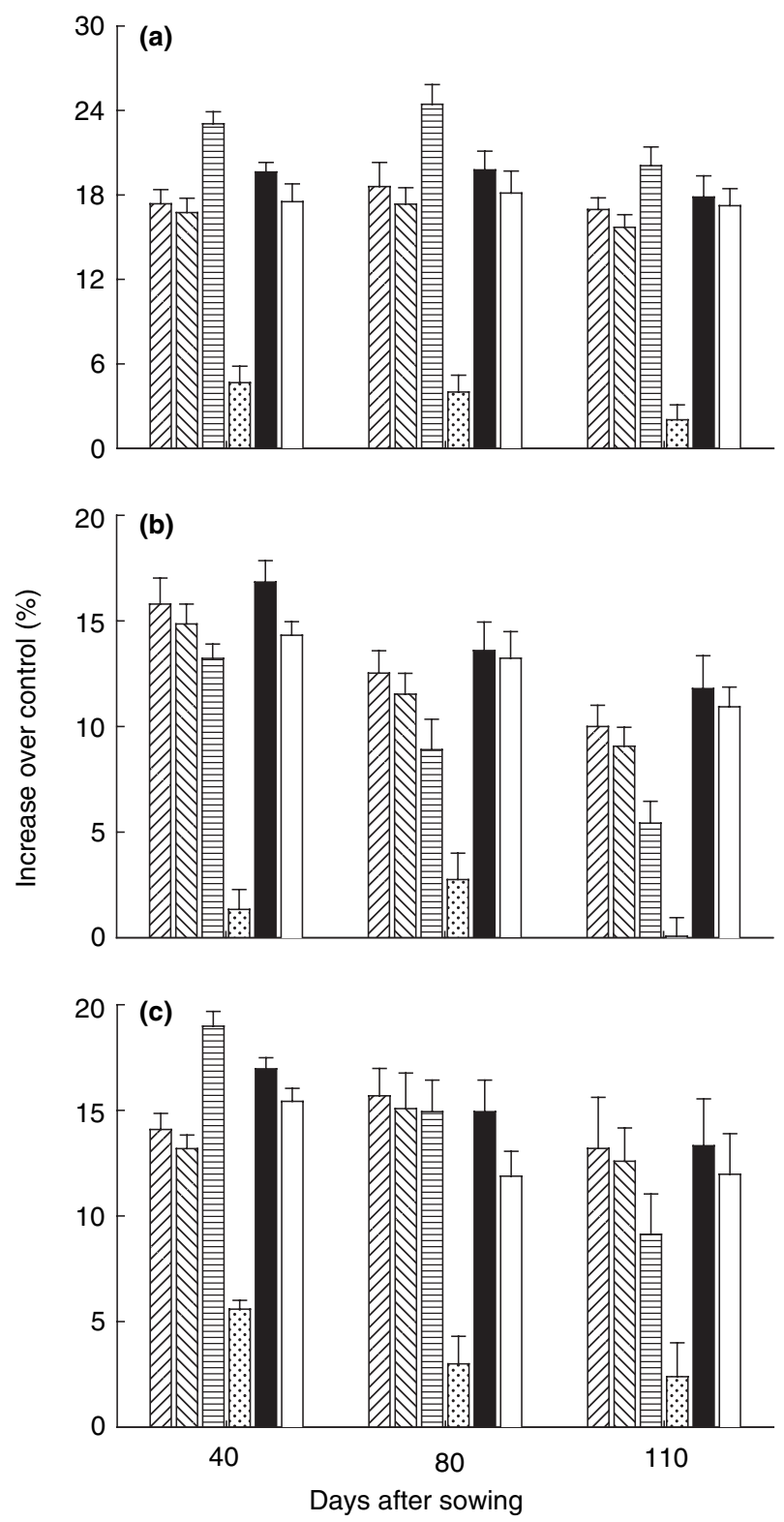

Fig. 4 Effect of selected groundnut-associated bacteria and their peat formulations applied as seed treatment on the growth of groundnut in field, in terms of (a) root length, (b) shoot length, and (c) dry biomass. The treatments evaluated were as follows: $(\square)$ actively growing cells of GRS 123, $(\nabla)$ peat formulation of GRS 123 , (曰) actively growing cells of GPS 21, () peat formulation of GPS 21, ( $\mathbf{\square}$ ) actively growing cells of GPS 55, and ( $\square$ ) peat formulation of GPS 55. Data presented is the mean and standard error of six replications in a repeated field experiment 


\section{Evaluation of peat-based formulations of selected isolates in field}

Bacillus firmis GRS 123 and B. megaterium GPS 55 had a good shelf-life of $\log 7 \cdot 7$ and $7 \cdot 1 \mathrm{CFU} \mathrm{g}^{-1}$, in peat up to 180 DAI (Fig. 3). Initial population of $P$. aeruginosa GPS 21, $\log 7 \cdot 5 \mathrm{CFU} \mathrm{g}^{-1}$, decreased to $\log 3 \cdot 3 \mathrm{CFU} \mathrm{g}^{-1}$ by 120 DAI, beyond which the bacterium was not recovered from the formulation.

Seed treatment with actively growing cells of $B$. firmis GRS $123, B$. megaterium GPS 55 and $P$. aeruginosa GPS 21 increased the seedling emergence, shoot and root length, dry biomass and yield of groundnut in the field (Fig. 4; Table 3). Peat formulations of GRS 123 and GPS 55 were as effective as the actively growing cells, whereas the peat formulation of GPS 21 was similar to the CMC control in plant growth promotion. Maximum increase in root length $(25 \%)$ and shoot length $(17 \%)$ was recorded in GPS 21- and GPS 55-treated seedlings at 60 and 40 DAS respectively (Fig. 4a,b). Maximum dry weight was observed in GPS 21-treated plants up to 60 DAS. At harvest, GPS 55-treated plants had a maximum dry biomass, which is $13 \%$ higher than the CMC-treated control (Fig. 4c).

Seed treatment with GRS 123, GPS 55 and GPS 21 increased the pod yield of field-grown groundnut by 16, 19 and 15\% respectively (Table 3). Peat formulations of zGRS 123 and GPS 55 were comparable $(P=0.05)$ to the actively growing cells, while the peat formulation of GPS 21 had no effect on the pod yield compared with control.

\section{Rhizosphere colonization of growth promoting bacteria in field}

In the groundnut ectorhizosphere, GRS $123-\mathrm{R}_{1}$ and GPS $55-\mathrm{R}_{1}$ were detectable $\left(\log 3 \cdot 6\right.$ and $3 \cdot 1 \mathrm{CFU} \mathrm{g}^{-1}$ respectively) up to 100 DAS (Fig. 5). In contrast, the population of

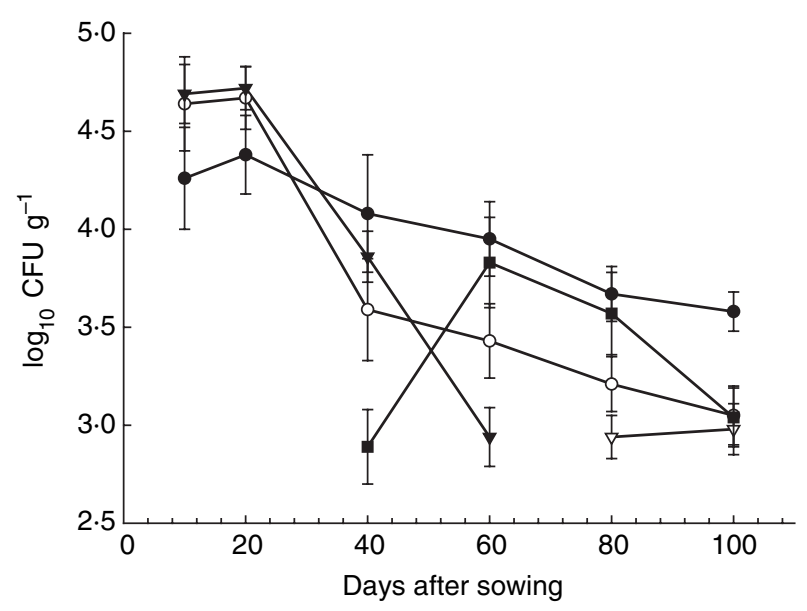

Fig. 5 Survival of rifampicin resistant mutants (-) Bacillus firmis GRS $123-\mathrm{R}_{1}$ in the ectorhizosphere, $(\bigcirc)$ Bacillus megaterium GPS 55$\mathrm{R}_{1}$ in the ectorhizosphere, $(\boldsymbol{\nabla})$ Pseudomonas aeruginosa GPS 21- $\mathrm{R}_{1}$ in the ectorhizosphere, $(\nabla)$ GPS $55-R_{1}$ in the endorhizosphere, and ( $\square$ ) GPS 21- $\mathrm{R}_{1}$ in the endorhizosphere of groundnut in field. GRS $123-\mathrm{R}_{1}$ was not observed in the endorhizosphere throughout the crop season. Mean values and standard errors are calculated based on six replications of each treatment in a repeated field experiment

GPS $21-\mathrm{R}_{1}$ decreased to $\log 2.9 \mathrm{CFU} \mathrm{g}^{-1}$ by 60 DAS and was not detectable further. In the endorhizosphere, GPS 21$\mathrm{R}_{1}$ and GPS 55- $\mathrm{R}_{1}$ were recovered from 40 and 80 DAS respectively. Maximum populations of these two isolates in the endorhizosphere were recorded as $\log 3.8$ and $3 \cdot 0 \mathrm{CFU} \mathrm{g}^{-1}$.

\section{DISCUSSION}

Groundnut-associated bacteria isolated from various habitats, that is, rhizosphere, phylloplane, geocarposphere and seed endophytes promoted the early plant growth of groundnut in the greenhouse. Maximum increase in plant

\begin{tabular}{llll}
\hline Isolate & Treatment* & Emergence (\%) & Yield (t ha $\left.{ }^{-1}\right)$ \\
\hline Bacillus firmis GRS 123 & Actively growing ells & $95 \cdot 3 \pm 3 \cdot 1$ & $1 \cdot 32 \pm 0 \cdot 10$ \\
Bacillus firmis GRS 123 & Peat formulation & $94 \cdot 4 \pm 2 \cdot 2$ & $1 \cdot 29 \pm 0 \cdot 14$ \\
Bacillus megaterium GPS 55 & Actively growing cells & $97 \cdot 9 \pm 1 \cdot 0$ & $1 \cdot 35 \pm 0 \cdot 11$ \\
Bacillus megaterium GPS 55 & Peat formulation & $92 \cdot 4 \pm 4 \cdot 5$ & $1 \cdot 34 \pm 0 \cdot 15$ \\
Pseudomonas aeruginosa GPS 21 & Actively growing cells & $96 \cdot 3 \pm 1 \cdot 7$ & $1 \cdot 30 \pm 0 \cdot 13$ \\
Pseudomonas aeruginosa GPS 21 & Peat formulation & $85 \cdot 7 \pm 1 \cdot 9$ & $1 \cdot 14 \pm 0 \cdot 06$ \\
Control & & $82 \cdot 4 \pm 4 \cdot 4$ & $1 \cdot 13 \pm 0 \cdot 10$ \\
LSD $(P=0 \cdot 05)$ & & $2 \cdot 97$ & $0 \cdot 13$ \\
\hline
\end{tabular}

*Actively growing cells and peat formulation were applied as seed treatment in groundnut cv. TMV 2 using $0.5 \%$ CMC as an adhesive. Seedling emergence was observed 15 days after sowing (DAS) and pod yield was recorded at harvest (110 DAS). Data points are the mean of six replications of a repeated field experiment.
Table 3 Emergence promotion and yield increase by selected groundnut-associated rhizosphere and phylloplane bacteria, and their peat formulations 
biomass was observed by seed treatment with $B$. firmis GRS 123 from rhizosphere, and B. megaterium GPS 55 and $P$. aeruginosa GPS 21 from phylloplane of groundnut. PGPR-mediated growth promotion has been observed in other legumes such as chickpea (Trapero-Casas et al. 1990) and soyabean (Zhang et al. 1997). Bacterial isolates that promote early plant growth are rapid colonizers of the root system. The use of unsterilized soil for initial screening further facilitates the identification of growth-promoting isolates with rhizosphere competence.

In the present study, the percentage of auxin producers and mineral phosphate solubilizers was high among the growth-promoting isolates compared with the 393 test isolates. However, there was no relation between the in vitro auxin production and increase in root length/plant growth by the bacterial isolates. A positive correlation between L-tryptophan-derived auxin production and growth promoting activities of PGPR has been reported (Asghar et al. 2002; Khalid et al. 2004). The differences in the performance of auxin-producing PGPR could be due to the greater dependency on the availability of L-tryptophan in the root exudates for production of bacterial auxins. Moreover, the optimal concentration of auxin required for plant growth promotion is extremely narrow (Xie et al. 1996) and doses of auxin above the threshold levels are deleterious for root growth.

Selected bacterial isolates B. firmis GRS 123, B. megaterium GPS 55 and $P$. aeruginosa GPS 21 promoted seedling emergence, root length, shoot length, dry weight and pod yield of groundnut in the field. Earlier studies on groundnut PGPR were focused on rhizobacterial isolates of Pseudomonas sp., which effectively colonized the rhizosphere and enhanced biomass, nitrogen and phosphorous uptake, and yield (Pal et al. 2000). Pseudomonas sp. GRC 2 increased the germination, plant growth, nodule weight and grain yield of groundnut in addition to control of charcoal rot caused by Rhizoctonia bataticola (Gupta et al. 2002). In the present study a similar increase in the growth and yield of groundnut was observed with a phylloplane isolate of $P$. aeruginosa. GRS 123, GPS 55 and GPS 21 were potent siderophore producers on chrome azurol $\mathrm{S}$ medium, while GPS 21 was also a broad-spectrum antifungal strain (Kishore et al. 2005).

Peat formulations of B. firmis GRS 123 and B. megaterium GPS 55 maintained high populations up to $180 \mathrm{DAI}$, while $P$. aeruginosa GPS 21 was not recovered beyond 120 DAI. Pseudomonas spp. have a short shelf-life compared with spore-forming bacilli (Georgakopoulos et al. 2002). Storage of Pseudomonas spp. for $>6$ months in peat without decrease in populations and effectiveness (Vidhyasekaran and Muthamilan 1995; Georgakopoulos et al. 2002) further indicates the possibility of developing formulations of pseudomonads with long shelf-life. In the present study, the field performance of peat formulations of rhizobacteria and phylloplane bacteria as groundnut PGPR was related to the viable cell numbers in these formulations.

Root colonization by PGPR is critical in biological control and plant growth promotion (Kloepper and Beauchamp 1992). Root colonization is highly variable as it is affected by complex interactions of chemical, physical and biological factors (Weller 1988). Determining the dynamics of root colonization by the introduced PGPR is essential for their effective use. We compared the rhizosphere colonization of selected growth-promoting phylloplane bacteria with a rhizobacterium for further understanding of the growth promotion by phylloplane bacteria. The selected phylloplane bacteria, when introduced into the rhizosphere, were able to colonize the ecto- and endorhizospheres of groundnut. The results showed that B. megaterium GPS 55 colonized the ecto- and endorhizosphere till 100 DAS, whereas $P$. aeruginosa GPS 21 colonized the ectorhizosphere up to 60 DAS and was present in the endorhizosphere till 100 DAS. It has been previously observed that Bacillus and Pseudomonas sp. applied as seed treatment colonize the endorhizosphere and increase the plant biomass (Chanway et al. 2000).

The present study indicated that the bacterial isolates from habitats like phylloplane and endophytes were also effective, like rhizobacteria, in plant growth promotion when applied as seed treatment. Phylloplane isolates normally survive in low moisture and other adverse conditions, thus may effectively colonize the nutrient-rich rhizosphere. Majority of the selected PGPR were rhizobacteria and it may be possible to select better plant growth-promoting bacteria from parts of the plants other than roots.

\section{ACKNOWLEDGEMENTS}

We acknowledge the financial support given by the Andhra Pradesh-Netherlands Biotechnology Program (ABNBP), Institute of Public Enterprises (Hyderabad, India) and the Department for International Development (UK) to A.R.P. and S.P., respectively, to carry out this research work. GKK thanks the APNLBP for the Senior Research Fellowship. ARP and GKK also thank the UGC-SAP and DST-FIST programmes of the Department of Plant Sciences (University of Hyderabad).

\section{REFERENCES}

Andrews, J.H. (1992) Biological control in the phyllosphere. Annu Rev Phytopathol 30, 603-635.

Asghar, H.N., Zahir, Z.A., Arshad, M. and Khaliq, A. (2002) Relationship between in vitro production of auxins by rhizobacteria and their growth-promoting activities in Brassica juncea L. Biol Fertil Soils 35, 231-237. 
Bric, J.M., Bostock, R.M. and Silverstone, S.E. (1991) Rapid in vitro assay for indoleacetic acid production by bacteria immobilized on a nitrocellulose membrane. Appl Environ Microbiol 57, 535-538.

Chanway, C.P., Shishido, M., Narin, J., Jungwirth, S., Markham, J., Xiao, G. and Holl, F.B. (2000) Endophytic colonization and field responses of hybrid spruce seedlings after inoculation with plant growth-promoting rhizobacteria. Forest Ecol Manag 133, 81-88.

Georgakopoulos, D.G., Fiddaman, P., Leifert, C. and Malathrakis, N.E. (2002) Biological control of cucumber and sugar beet dampingoff caused by Pythium ultimum with bacterial and fungal antagonists. I Appl Microbiol 92, 1078-1086.

Gupta, C.P., Dubey, R.C. and Maheshwari, D.K. (2002) Plant growth enhancement and suppression of Macrophomina phaseolina causing charcoal rot of peanut by fluorescent Pseudomonas. Biol Fertil Soils 35, 399-405.

Jacoud, C., Job, D., Wadoux, P. and Bally, R. (1999) Initiation of root growth stimulation by Azospirillum lipoferum CRT1 during maize seed germination. Can 7 Microbiol 45, 339-342.

Khalid, A., Arshad, M. and Zahir, Z.A. (2004) Screening plant growthpromoting rhizobacteria for improving growth and yield of wheat. 7 Appl Microbiol 96, 473-480.

Kishore, G.K., Pande, S. and Podile, A.R. (2005) Biological control of collar rot disease with broad-spectrum antifungal bacteria associated with groundnut. Can $\mathcal{7}$ Microbiol (in press).

Kloepper, J.W. (1993) Plant growth-promoting rhizobacteria as biological control agents. In Soil Microbial Ecology ed. Metting, F.B. Jr. pp. 255-274. New York: Marcel Dekker, Inc.

Kloepper, J.W. and Beauchamp, C.J. (1992) A review of issues related to measuring colonization of plant roots by bacteria. Can 7 Microbiol 38, 1219-1232.

Kloepper, J.W. and Schroth, M.N. (1978) Plant growth-promoting rhizobacteria on radishes. In Proceedings of the Fourth International Conference on Plant Pathogenic Bacteria, Vol. 2 ed. Ridè, M. pp. 879-882. Tours, France: Gibert-Clarey.

Kloepper, J.W., Zablokovicz, R.M., Tipping, E.M. and Lifshitz, R. (1991) Plant growth promotion mediated by bacterial rhizosphere colonizers. In The Rhizosphere and Plant Growth ed. Keister, D.L. and Cregan, P.B. pp. 315-326. the Netherlands: Kluwer Academic Publishers.
Manjula, K., Singh, S.D. and Kishore, G.K. (2002) Role of endophytic bacteria in biological control of plant diseases. Annu Rev Plant Pathol $1,231-252$.

Pal, K.K., Dey, R., Bhatt, D.M. and Chauhan, S.M. (2000) Plant growth promoting fluorescent pseudomonads enhanced peanut growth, yield and nutrient uptake. In Proceedings of the Fifth International PGPR Workshop, 29 October to 2 September, 2000. Cordoba, Argentina (http://www.ag.auburn.edu/argentina/ pdfmanuscripts/pal.pdf; accessed on 25/6/04).

Pikovsky, R.I. (1948) Mobilization of phosphorous in connection with the vital activity of some microbial species. Microbiologia 17, 362-370.

Podile, A.R. and Dube, H.C. (1988) Plant growth-promoting activity of Bacillus subtilis AF 1. Curr Sci 57, 183-186.

Preeti, V., Reddy, M.S., Kavitha, S., Velusamy, P., PaulRaj, R.S.D., Purushothaman, S.M., Priyadarisini, V.B., Kumar, S.B. et al. (2002) Role of biological preparations in enhancement of rice seedling growth and grain yield. Curr Sci 83, 1140-1143.

Ryu, C.M., Farag, M.A., Hu, C.H., Reddy, M.S., Wei, H.X., Pare, P.W. and Kloepper, J.W. (2003) Bacterial volatiles promote growth in Arabidopsis. Proc Natl Acad Sci USA 100, 4927-4932.

Sessitsch, A., Reiter, B. and Berg, G. (2004) Endophytic bacterial communities of field-grown potato plants and their plant-growthpromoting and antagonistic abilities. Can 7 Microbiol 50, 239-249.

Trapero-Casas, A., Kaiser, W.J. and Ingram, D.M. (1990) Control of pythium seed rot and preemergence damping-off of chickpea in the U.S. Pacific Northwest and Spain. Plant Dis 74, 563-569.

Vidhyasekaran, P. and Muthamilan, M. (1995) Development of formulations of Pseudomonas fluorescens for control of chickpea wilt. Plant Dis 79, 782-786.

Weller, D.M. (1988) Biological control of soilborne plant pathogens in the rhizosphere with bacteria. Annu Rev Phytopathol 26, 379-407.

Xie, H., Pasternak, J.J. and Glick, B.R. (1996) Isolation and characterization of mutants of the plant growth-promoting rhizobacterium Pseudomonas putida GR12-2 that overproduce indoleacetic acid. Curr Microbiol 32, 67-71.

Zhang, F., Dashti, N., Hynes, R.K. and Smith, D.K. (1997) Plant growth-promoting rhizobacteria and soybean [Glycine max (L.) Merr.] growth and physiology at suboptimal root zone temperatures. Ann Bot 79, 243-249. 
Copyright of Letters in Applied Microbiology is the property of Blackwell Publishing Limited and its content may not be copied or emailed to multiple sites or posted to a listserv without the copyright holder's express written permission. However, users may print, download, or email articles for individual use. 